\title{
CHROMIUM (III) COMPLEX ANIONS IN THE CHEMICAL ANALYSIS. ATROPINE DETERMINATION
}

\author{
Ion Gănescu, Aurora Reiss, Alin Barbu and Anca Gănescu \\ University of Craiova, Faculty of Chemistry, 13 A. I. Cuza, 1100 Craiova, Romania
}

\begin{abstract}
Complex anions or Cr(III) analogues of Reinecke's salt, $\left[\mathrm{Cr}(\mathrm{NCS})_{2}(\mathrm{amine})_{2}\right]^{-}$ are good analytical reagents with high sensibility and selectivity for $N$-organic bases of pharmaceutical importance. We have observed that the atropine with Cr(III) complex anions. Some new oxidative methods for determination of atropine are described. The results were evaluated statistically.
\end{abstract}

KEYWORDS: chromium (III), atropine, drugs, oxidimetric and spectrometric methods.

\section{RESUMO}

Complexos aniónicos de Cr(III), análogos do sal de Reinecke, são reagentes analíticos excelentes a possuem sensibilidade e seletividade alta para para bases orgánicas de $N$ que tem importancia farmacéutica. O presente estudo demonstrou que a atropina forma precipitados com aniones complexos de $\mathrm{Cr}$ (III). Os resultados experimentáis foram avaliados estatisticamente.

\section{INTRODUCTION}

Atropine is the ester of the tropic acid with tropanol. This alkaloide is found along with other compounds with similar structure in the leaves, the seeds and the roots of some plants from Solanaceae family: "Atropa belladona,Datura stramonium and Hyoscyamus niger".

Atropine is racemic form and always accompanies hiosciamine which is its levogyre isomer.

It has been proved that the atropine is formed by the partial racemization of the hiosciamine during the drying of these vegetal products as well as during the isolation of the alkaloide, but it has been found as such in the plants mentioned above.

For the industrial extraction of this alkaloide the dry or fresh vegetal material, is impregnated with a $10 \% \mathrm{Na}_{2} \mathrm{CO}_{3}$ solution and then is put into an extraction apparatus where is used up with ether. After removing the ether, the solution lets an oily liquid.

By adding 5\% acetic acid, the alkaloides in the oily liquid are transformed in acetates, which are held in a cold place for 24 hours. Then, they are filtered, are neutralized with ammonium hydroxide and they are alkalinized with potassium carbonate till the appearance of an opalescence.

From this solution, the crude alkaloide precipitates in a crystalline form which is filtered, washed with distilled water and is dried in air '. 
The crude product is dissolved in ether in order to be purified and animal coal is added for discolouring. The ether can be replaced with other solvents like a mixture of benzene and gazoline.

The pure product obtained after moving off the solvent at $120^{\circ} \mathrm{C}$ during a few hours, is filtered, is washed with acetone and is dried in the open air.

The structure formulae of this alkaloide was established through degradation reactions (hydrolysis, oxidation, etc.).

Willstätter's works contain a complete study about the structure of this alkaloide.

Atropine is hydrolyzsed in tropanol and tropic acid under the action of concentrated $\mathrm{HCl}$ and $\mathrm{Ba}(\mathrm{OH})_{2}$ as follows:

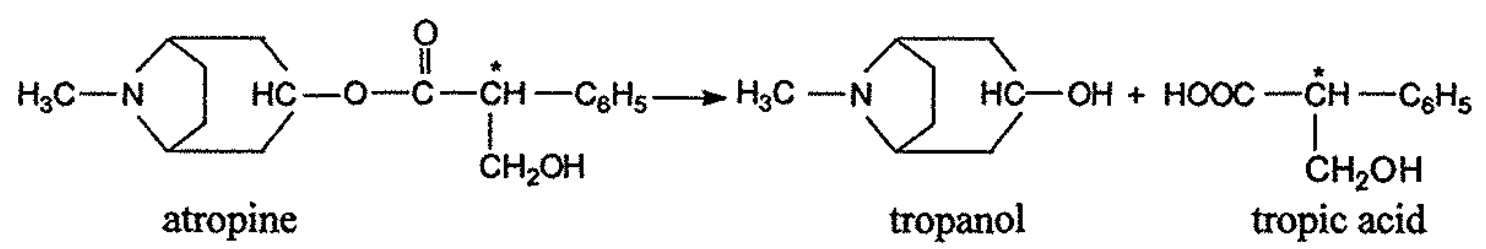

The atropine is a base which forms crystalline salts with the mineral acids. It precipitates with picric acid and forms an yellow picrate with $175^{\circ} \mathrm{C}$ melting point; with $\mathrm{H}_{2}\left[\mathrm{PtCl}_{6}\right]$ the atropine forms an yellow precipitate with a melting point of $207^{\circ} \mathrm{C}$ and with $\mathrm{H}\left[\mathrm{AuCl}_{4}\right]$ also forms an yellow precipitate but with a melting point of $136^{\circ} \mathrm{C}$ etc.

Two colour reactions are used for the identification of the atropine, for example: formulae:

$>$ Vitali's reaction, which is a nitration reaction of tropic acid with the

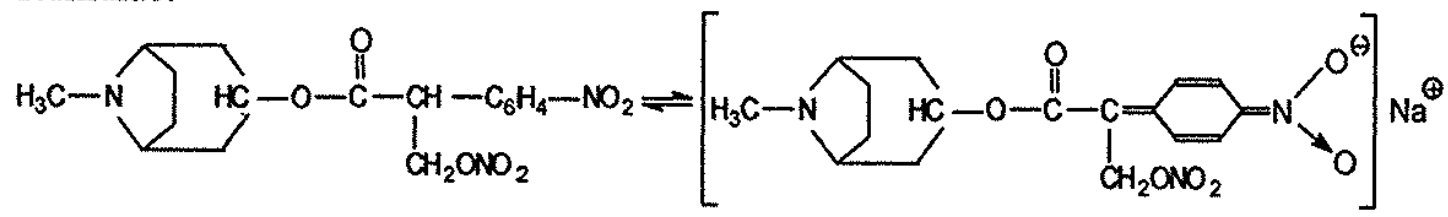

$>$ Wasicky's reaction with p-dimethyl-aminobenzaldehyde in $\mathrm{H}_{2} \mathrm{SO}_{4}$ when a red-violet colour is obtained.

The atropine sulphate is more used in therapy then the valerianate. The atropine sulphate is a crystalline chemical compound, without aroma, and with bitter sour taste.

It is melted at $195^{\circ} \mathrm{C}$ and is soluble in water and alcohol in 1:1 molar raport, insoluble in ether, chloroform and benzene. The aqua solution has a neutral reaction.

The structural formulae of the sulphate atropine is as follows:<smiles>CN1C2CCC1CC(OC(=O)C(CO)(CO)CC(=O)O)C2</smiles>

Vitali's reaction is used for the identification of the alkaloide and the reaction with $\mathrm{BaCl}_{2}$ is used for the sulphate anion.

The quantitative determination of the sulphate atropine is done acido-basic in non aqua medium with $0.1 \mathrm{~N}$ perchloric acid in acetic acid using as titration medium a 
mixture of acetic acid and acetic anhydride and as indicator alpha naphtol benzeine when a green colour is obtained.

The atropine has parasympatholytic action: it relaxes the muscles of the gastrointestinal and genito-urinary tract, and the biliary muscles. The atropine is used in ophthalmology and because of its pain-killer action is utilized as ointment for neuralgia and for hemorrhoidal pain. The atropine is preserved in airtight bottles.

\section{EXPERIMENTAL PROCEDURE. RESULTS AND DISCUSSIONS}

\section{The synthesis of the complex salts of the type}

Atropine.H[Cr(NCS $\left.)_{4}(\text { ammine })_{2}\right]$

20 Mmoles atropine sulphate are acidulated with $10 \mathrm{~mL}$ of $1 \mathrm{~N} \mathrm{H}_{2} \mathrm{SO}_{4}$ and then 80-100 mL distilled water are added.

The atropine sulphate is precipitated with 10 Mmoles reagent of the type tetratiocianatochromat (III) which is dissolved in $15 \mathrm{~mL}$ ethanol. A crystalline precipitate with a red-violet colour is formed and after 10-15 minutes it is filtered under vacuum $^{2,3,4}$.

The precipitate is washed with distilled water till the filtrate becomes colorless and then it is laid down at air to dry

The experimental results are presented in table 1.

Table 1. New complex salts of the type Atropine $\cdot \mathrm{H}\left[\mathrm{Cr}(\mathrm{NCS})_{4}(\text { ammine })_{2}\right]$

\begin{tabular}{|c|c|c|c|c|c|c|c|}
\hline \multirow[b]{2}{*}{ No. } & \multirow{2}{*}{ The combination } & \multirow{2}{*}{$\begin{array}{l}\text { Molecular } \\
\text { weight } \\
\text { calcd. }\end{array}$} & \multirow{2}{*}{$\begin{array}{c}\text { Yield } \\
\%\end{array}$} & \multirow{2}{*}{$\begin{array}{c}\text { Solubility } \\
\mathrm{mol} / \mathrm{L}\end{array}$} & \multirow{2}{*}{$\begin{array}{c}\text { Microcrystalline } \\
\text { aspect }\end{array}$} & \multicolumn{2}{|c|}{ Analysis \% } \\
\hline & & & & & & Calcd. & Found \\
\hline 1 & $\mathrm{AH}\left[\mathrm{Cr}(\mathrm{NCS})_{4}\left(\mathrm{NH}_{3}\right)_{2}\right]$ & 588,75 & 91 & $3 \cdot 10^{-2}$ & $\begin{array}{c}\text { Violet-red } \\
\text { microcrystales }\end{array}$ & \begin{tabular}{|l|}
$\mathrm{Cr}: 8,83$ \\
$\mathrm{~S}: 21,78$ \\
$\mathrm{~N}: 16,64$ \\
\end{tabular} & \begin{tabular}{|l|}
8,77 \\
21,66 \\
16,55 \\
\end{tabular} \\
\hline 2 & $\mathrm{AH}\left[\mathrm{Cr}(\mathrm{NCS})_{4}(\text { aniline })_{2}\right]$ & 760,88 & 98 & $1,8 \cdot 10^{-2}$ & $\begin{array}{c}\text { Violet-red } \\
\text { microcrystales }\end{array}$ & \begin{tabular}{l|}
$\mathrm{Cr}: 6,83$ \\
$\mathrm{~S}: 16,85$ \\
$\mathrm{~N}: 12,87$ \\
\end{tabular} & \begin{tabular}{|l|}
6,80 \\
16,70 \\
12,69 \\
\end{tabular} \\
\hline 3 & AH[Cr(NCS $\left.)_{4}(\text { benzilamine })_{2}\right]$ & 788,88 & 96 & $1,9 \cdot 10^{-2}$ & $\begin{array}{c}\text { Violet-red } \\
\text { microcrystales }\end{array}$ & \begin{tabular}{|l|}
$\mathrm{Cr}: 6,59$ \\
$\mathrm{~S}: 16,25$ \\
$\mathrm{~N}: 12,42$ \\
\end{tabular} & \begin{tabular}{|l|}
6,48 \\
16,16 \\
12,33 \\
\end{tabular} \\
\hline 4 & $\mathrm{AH}\left[\mathrm{Cr}(\mathrm{NCS})_{4}(\text { imidazole })_{2}\right]$ & 711,04 & 88 & $6 \cdot 10^{-2}$ & $\begin{array}{c}\text { Violet-red } \\
\text { microcrystales }\end{array}$ & \begin{tabular}{|l|}
$\mathrm{Cr}: 7,31$ \\
$\mathrm{~S}: 18,03$ \\
$\mathrm{~N}: 17,72$ \\
\end{tabular} & \begin{tabular}{|l|}
7,29 \\
17,88 \\
17,57 \\
\end{tabular} \\
\hline 5 & $\mathrm{AH}\left[\mathrm{Cr}(\mathrm{NCS})_{4}(\text { benztriazole })_{2}\right]$ & 813,92 & 94 & $2,5 \cdot 10^{-2}$ & $\begin{array}{c}\text { Violet-red } \\
\text { microcrystales }\end{array}$ & $\begin{array}{l}\text { Cr:6,39 } \\
\mathrm{S}: 15,75 \\
\mathrm{~N}: 18,92 \\
\end{array}$ & \begin{tabular}{|l|}
6,27 \\
15,70 \\
18,88 \\
\end{tabular} \\
\hline 6 & $\mathrm{AH}\left[\mathrm{Cr}(\mathrm{NCS})_{4}(\text { urotropine })_{2}\right]$ & 855,02 & 93 & $4 \cdot 10^{-2}$ & $\begin{array}{c}\text { Violet-red } \\
\text { microcrystales }\end{array}$ & \begin{tabular}{|l|}
$\mathrm{Cr}: 6,08$ \\
$\mathrm{~S}: 14,99$ \\
$\mathrm{~N}: 21,28$
\end{tabular} & \begin{tabular}{|l|}
6,03 \\
14,93 \\
21,24
\end{tabular} \\
\hline
\end{tabular}

$A=$ atropine

Chromium was determinated as $\mathrm{Cr}_{2} \mathrm{O}_{3}$; sulphur was determinated as $\mathrm{BaSO}_{4}$; nitrogen was determinated by combustion. 
Gravimetric determination of atropine as Atropine $\mathrm{H}\left[\mathrm{Cr}(\mathrm{NCS})_{4}\left(\mathrm{NH}_{3}\right)_{2}\right]$ (A) and Atropine $\cdot \mathrm{H}\left[\mathrm{Cr}(\mathrm{NCS})_{4}\right.$ (aniline) $\left.{ }_{2}\right]$ (B)

A sample of $1.67-16.7 \mathrm{mg}$ atropine is acidulated with $5 \mathrm{~mL} 0,1 \mathrm{HCl}$ and then it is precipitated with the analytical reagent into a $3 \%$ alcohol - water solution.

The obtained precipitate is filtered with a $\mathrm{G}_{4}$ crucible, is washed 3-4 times with $10 \mathrm{~mL} 3 \%$ alcohol - water solution till the filtrate flows colourless. The precipitate is dried one hour at $105^{\circ} \mathrm{C}$ into an oven ${ }^{5,6}$.

The experimental results are presented in table 2 .

Table 2. Gravimetric determination of atropine as Atropine $\mathrm{H}\left[\mathrm{Cr}(\mathrm{NCS})_{4}\left(\mathrm{NH}_{3}\right)_{2}\right]$ (A) and Atropine $\cdot \mathrm{H}\left[\mathrm{Cr}(\mathrm{NCS})_{4}(\text { aniline })_{2}\right](\mathrm{B})$

\begin{tabular}{|c|c|c|c|c|c|c|c|c|c|}
\hline \multirow{4}{*}{ No. } & \multirow{4}{*}{$\begin{array}{c}\text { Atropine } \\
\text { taken } \\
\text { mg }\end{array}$} & \multicolumn{8}{|c|}{ The form of determination } \\
\hline & & \multicolumn{4}{|c|}{$\mathrm{A}$} & \multicolumn{4}{|c|}{$\bar{B}$} \\
\hline & & \multirow{2}{*}{$\begin{array}{l}\mathrm{G}_{\text {complex }} \\
\text { found } \\
\text { mg }\end{array}$} & \multirow{2}{*}{$\begin{array}{c}\text { Atropine } \\
\text { found } \\
\text { mg }\end{array}$} & \multicolumn{2}{|c|}{ Error } & \multirow{2}{*}{$\begin{array}{l}\mathrm{G}_{\text {complex }} \\
\text { found } \\
\mathrm{mg}\end{array}$} & \multirow{2}{*}{$\begin{array}{l}\text { Atropine } \\
\text { found } \\
\text { mg }\end{array}$} & \multicolumn{2}{|c|}{ Error } \\
\hline & & & & mg & $\%$ & & & $\mathrm{mg}$ & $\%$ \\
\hline 1 & 1.67 & 3.38 & 1.66 & -0.01 & 0.60 & 4.37 & 1.66 & -0.01 & 0.59 \\
\hline 2 & 3.34 & 6.78 & 3.33 & -0.01 & 0.29 & 8.76 & 3.33 & -0.01 & 0.30 \\
\hline 3 & 6.68 & 13.56 & 6.66 & -0.02 & 0.29 & 17.63 & 6.70 & +0.02 & 0.30 \\
\hline 4 & 10.02 & 20.37 & 10.01 & -0.01 & 0.09 & 26.31 & 10.00 & -0.02 & 0.20 \\
\hline 5 & 13.36 & 27.23 & 13.38 & +0.02 & 0.15 & 35.17 & 13.37 & +0.01 & 0.07 \\
\hline 6 & 16.70 & 33.97 & 16.69 & -0.01 & 0.18 & 43.88 & 16.68 & -0.02 & 0.12 \\
\hline & & $\begin{array}{l}\mathrm{M}_{\mathrm{A}}=5 \\
\bar{X}=10 \\
\mathrm{~S}=2.5 \\
\mathrm{t}_{\mathrm{n}-1, a}= \\
\bar{X}-\mathrm{t} \cdot \\
10.01\end{array}$ & $\begin{array}{l}38.75 ; f_{A}= \\
03 ; S^{2}=6 \\
\cdot 10^{-2} ; t=0 \\
37 ; \alpha=95 \\
<A<\bar{X} \\
10.02<10\end{array}$ & $\begin{array}{l}.4914 \\
3 \cdot 10^{-4} \\
0 \\
\% \\
6 ; \\
t \cdot S \\
34\end{array}$ & & $\begin{array}{l}M_{B}=7 \\
\bar{X}=13 \\
S=2.2 \\
t_{n-1, \alpha}= \\
\bar{X}-t \cdot \\
13.35\end{array}$ & $\begin{array}{l}.88 ; f_{B}= \\
7 ; S^{2}=5 . \\
10^{-2} ; t=0 \\
37 ; \alpha=95 \\
<A<\bar{X} \\
3.36<13\end{array}$ & $\begin{array}{l}.3802 ; \\
0^{-4} ; \\
45 ; \\
\% ; \\
\text { t.S; } \\
38\end{array}$ & \\
\hline
\end{tabular}

The oxidimetric determination of atropine after precipitation as Atropine $\cdot \mathrm{H}\left[\mathrm{Cr}\left(\mathrm{NCS}_{4}\left(\mathrm{NH}_{3}\right)_{2}\right](\mathrm{A})\right.$, Atropine $\left.\cdot \mathrm{H}\left[\mathrm{Cr}(\mathrm{NCS})_{4} \text { (aniline }\right)_{2}\right]$ (B) respectively

1.67 - $13.36 \mathrm{mg}$ atropine are acidulated with $5 \mathrm{~mL} 0,1 \mathrm{M} \mathrm{HCl}$ then, the mentioned analytical reagent is added in water or $3 \%$ alcohol - water solution, when red-violet precipitates are formed. These precipitates are filtered and washed with distilled water till the filtrate flows colourless. The paper with the precipitate is brought into a $500 \mathrm{~mL}$ Berzelius glass together with $20 \mathrm{~mL} 5 \% \mathrm{NaOH}$ in order to decompose and to liberate $\mathrm{NCS}^{-}$anion.

Each sample is acidulated with $\mathrm{HCl}$ till the normal concentration becomes $1.7-2$ $\mathrm{N}$. The quantity of $\mathrm{HCl}$ is calculated using the relation:

$$
\mathrm{V}_{\mathrm{HCl}}=\frac{1.7\left(\mathrm{~V}_{\text {initial }}+\mathrm{V}_{\text {oxidizer }}\right)}{10.4}
$$


An amount of $5 \mathrm{~mL} \mathrm{CCl}_{4}$ and 10 drops of $\mathrm{ICl}$ indicator solution ${ }^{7}$ are added in the Berzelius glass and $\mathrm{NCS}^{-}$free is titrated with $0.1 \mathrm{~N} \mathrm{KMnO}_{4}, \mathrm{KBrO}_{3}$ or $\mathrm{KIO}_{3}$ solution under stirring. When the no watery stratum is discoloured the end of the titration may be considered

The advantage of this titration is the favorable stoechiometry, because one equivalent of $\mathrm{NCS}^{-}$consumes six equivalents of oxidizer $\left(\mathrm{KMnO}_{4}, \mathrm{KBrO}_{3}\right.$ or $\left.\mathrm{KIO}_{3}\right)$.

The reactions which take place are:

$5 \mathrm{NCS}^{-}+6 \mathrm{MnO}_{4}^{-}+13 \mathrm{H}^{+} \rightarrow 6 \mathrm{Mn}^{2+}+5 \mathrm{SO}_{4}^{2-}+5 \mathrm{HCN}+4 \mathrm{H}_{2} \mathrm{O}$

Respectively:

$2 \mathrm{NCS}^{-}+3 \mathrm{BrO}_{3}{ }^{-}+4 \mathrm{H}^{+} \rightarrow 2 \mathrm{SO}_{4}{ }^{2-}+3 \mathrm{Br}^{+}+2 \mathrm{HCN}+\mathrm{H}_{2} \mathrm{O}$

$2 \mathrm{NCS}^{-}+3 \mathrm{IO}_{3}^{-+}+4 \mathrm{H}^{+} \rightarrow 2 \mathrm{SO}_{4}^{2-}+3 \mathrm{I}^{+}+2 \mathrm{HCN}+\mathrm{H}_{2} \mathrm{O}$

The experimental results are presented in table 3:

Table 3. The oxidimetric determination of atropine after precipitation as Atropine $\cdot \mathrm{H}\left[\mathrm{Cr}(\mathrm{NCS})_{4}\left(\mathrm{NH}_{3}\right)_{2}\right]$, Atropine $\cdot \mathrm{H}\left[\mathrm{Cr}(\mathrm{NCS})_{4}(\text { aniline })_{2}\right]$ (B) respectively

\begin{tabular}{|c|c|c|c|c|c|c|}
\hline $\begin{array}{c}\text { Atropine } \\
\text { taken } \\
\text { mg }\end{array}$ & $\begin{array}{l}\text { No. } \\
\text { det. }\end{array}$ & $\begin{array}{c}\begin{array}{c}\text { Average of } \\
\text { determinations }\end{array} \\
\bar{X} \text { (mg) }\end{array}$ & $\begin{array}{l}\text { Square average } \\
\text { Error adequate one } \\
\text { determination (S) }\end{array}$ & $t_{a}$ & $t_{6}$ & $\begin{array}{c}t_{p-1, \alpha} \\
\alpha=95 \%\end{array}$ \\
\hline \multicolumn{7}{|c|}{ Permanganometric determination } \\
\hline 1.67 & 10 & 1.682 & $2.66 \cdot 10^{-2}$ & $4.7 \cdot 10^{-4}$ & $5.13 \cdot 10^{-2}$ & 2.57 \\
\hline 6.68 & 10 & 6.687 & $2.77 \cdot 10^{-2}$ & $0.28 \cdot 10^{-4}$ & $5.05 \cdot 10^{-2}$ & 2.57 \\
\hline \multicolumn{7}{|c|}{ Bromatometric determination } \\
\hline 3.34 & 10 & 3.332 & $1.94 \cdot 10^{-2}$ & $3.06 \cdot 10^{-4}$ & $5.03 \cdot 10^{-2}$ & 2.57 \\
\hline 10.02 & 10 & 10.029 & $2.52 \cdot 10^{-2}$ & $9.12 \cdot 10^{-4}$ & $4.98 \cdot 10^{-2}$ & 2.57 \\
\hline \multicolumn{7}{|c|}{ Iodatometric determination } \\
\hline 6.68 & 10 & 6.673 & $2.23 \cdot 10^{-2}$ & $26.66 \cdot 10^{-4}$ & $5.31 \cdot 10^{-2}$ & 2.57 \\
\hline 13.36 & 10 & 13.373 & $2.23 \cdot 10^{-2}$ & $21.89 \cdot 10^{-7}$ & $4.83 \cdot 10^{-2}$ & 2.57 \\
\hline
\end{tabular}

\section{Spectrometric determination of atropine with complexes anions of $\mathrm{Cr}$ (III)}

Amounts of $2.28-18.24 \mathrm{mg}$ atropine are acidulated with $5 \mathrm{~mL} 0.1 \mathrm{M} \mathrm{HCl}$, are completed till $50 \mathrm{~mL}$ with a $3 \%$ alcohol - water solution and is added ammonium rhodanilat $\left.\mathrm{H}_{4} \mathrm{~N}\left[\mathrm{Cr}(\mathrm{NCS})_{4} \text { (aniline) }\right)_{2}\right]$.

The obtained red-violet precipitate is filtered using a $G_{4}$ porosity glass filter, is washed 3 or 4 times with $10 \mathrm{~mL}$ alcohol-water (1:1) and then is dissolved in acetone. The obtained solution is brought into a $25 \mathrm{~mL}$ balloon and acetone is added till the sign. The absorbance is determinated at $540 \mathrm{~nm}$.

The experimental data were statistically interpreted through the linear regression method and they are presented in table 4: 
Table 4. Spectrometric determination of atropine as Atropine $\cdot \mathrm{H}\left[\mathrm{Cr}(\mathrm{NCS})_{4}(\text { aniline })_{2}\right]$

\begin{tabular}{|c|c|c|c|c|c|c|c|}
\hline No. & $\mathrm{X}(\mathrm{mg})$ & $\mathrm{X}^{2}$ & $\mathrm{Y}$ & $\mathrm{Y}^{2}$ & $\mathrm{X} \cdot \mathrm{Y}$ & $\mathrm{X}+\mathrm{Y}$ & $(\mathrm{X}+\mathrm{Y})^{2}$ \\
\hline 1 & 2.28 & 5.1984 & 0.04 & 0.0016 & 0.0912 & 2.32 & 5.3824 \\
\hline 2 & 4.56 & 20.7936 & 0.08 & 0.0064 & 0.3648 & 4.64 & 21.5296 \\
\hline 3 & 6.84 & 46.7856 & 0.11 & 0.0121 & 0.7524 & 6.95 & 48.3025 \\
\hline 4 & 9.12 & 83.1744 & 0.15 & 0.0225 & 1.3680 & 9.27 & 85.9329 \\
\hline 5 & 11.40 & 129.9600 & 0.19 & 0.0361 & 2.1660 & 11.59 & 134.3281 \\
\hline 6 & 13.68 & 187.1424 & 0.23 & 0.0529 & 3.1464 & 13.91 & 193.4881 \\
\hline 7 & 15.96 & 254.7216 & 0.27 & 0.0729 & 4.3092 & 16.23 & 263.4129 \\
\hline 8 & 18.24 & 332.6976 & 0.31 & 0.0961 & 5.6544 & 18.55 & 344.1025 \\
\hline Total & 82.08 & 1060.4736 & 1.38 & 0.3006 & 17.8524 & 83.46 & 1096.479 \\
\hline
\end{tabular}

Using the data presented in table 4 we can do the next calculations:

$$
\begin{aligned}
& \sum X^{2}+\sum Y^{2}+2 \sum X \cdot Y=1096.479 \\
& \sum(X+Y)^{2}=1096.479
\end{aligned}
$$

It is observed that both values are equal. This means that the method elaborated by us is reproducible and accurate.

The standard deviations and the regress coefficient are calculated thus:

$$
\begin{aligned}
& \sigma_{X}=\sqrt{\frac{\sum X^{2}}{n}-\bar{X}^{2}}=5.224 ; \bar{X}=10.26 \\
& \sigma_{Y}=\sqrt{\frac{\sum Y^{2}}{n}-\bar{Y}^{2}}=0.0884 ; \quad \bar{Y}=0.1725 \\
& r=\frac{\frac{\sum X Y}{n}-\bar{X} \cdot \bar{Y}}{\sigma_{X} \cdot \sigma_{Y}}=0.9998 \cong 1
\end{aligned}
$$

The value of $r$ shows that the results obtained by this method are reproducible and the error is negligible.

The equations infered through the method of linear regression, which show in the best way the dependence between the absorbance and the concentration of the active product in the sample $(\mathrm{mg})$ are the following:

$$
\begin{aligned}
& \mathrm{Y}-\overline{\mathrm{Y}}=\mathrm{r} \cdot \frac{\sigma_{\mathrm{Y}}}{\sigma_{\mathrm{X}}}(\mathrm{X}-\overline{\mathrm{X}}) ; \mathrm{Y}=0.0169185 \cdot \mathrm{X}-0.00108395 \\
& \mathrm{X}-\overline{\mathrm{X}}=\mathrm{r} \cdot \frac{\sigma_{\mathrm{X}}}{\sigma_{\mathrm{Y}}}(\mathrm{Y}-\overline{\mathrm{Y}}) ; \mathrm{X}=59.0832036 \cdot \mathrm{Y}+0.06814737
\end{aligned}
$$

The domain of concentrations in which the Lambert - Beer law is valid is contained between 0.0912 and $0.7296 \mathrm{mg}$ atropine.

The molar coefficient of absorbance is $\varepsilon=323.291 \cdot \mathrm{cm}^{-1} \cdot \mathrm{mol}^{-1}$.

The calibration curve for the spectrometric determination of atropine as Atropine $\cdot \mathrm{H}\left[\mathrm{Cr}(\mathrm{NCS})_{4}(\text { aniline })_{2}\right]$ is presented in the figure 1 . 
A 10

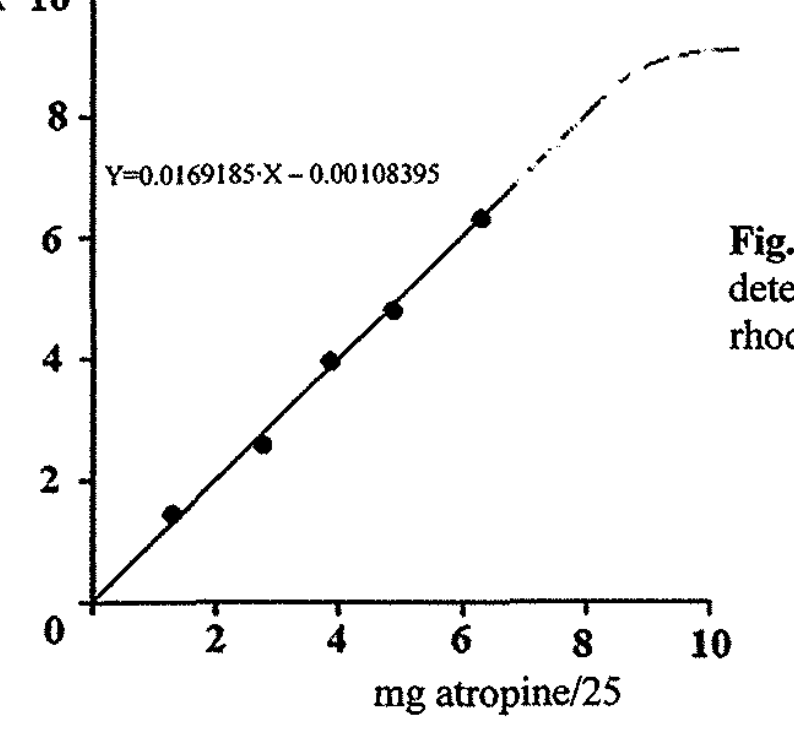

\section{CONCLUSIONS}

New methods of determination of atropine as Atropine $\mathrm{H}\left[\mathrm{Cr}(\mathrm{NCS})_{4}(\text { aniline })_{2}\right]$ were elaborated.

All the experimental results were statistically analysed and it came out that the methods elaborated by us are not affected by systematic errors, are rapid, accurate enough, so that we recommend these methods to be used in the laboratories of control and analyses of drugs.

\section{REFERENCES}

1. Zotta V., Chimie farmaceutică, Ed. medicală, Bucureşti, 483 (1985);

2. I. Gănescu, G. Brătulescu, V. Magearu, I. Papa and Anca Gănescu, Analele Universităţii din Bucureşti, anul XIII, vol. I-II, 57 (2004);

3. I. Gănescu, I. Papa, Anca Gănescu, G. Brătulescu, A. Barbu, Acta Chimica Slovenica, 49, 181, (2002);

4. I. Gănescu, C. Mircioiu, I. Papa, A. Gănescu, V. Aldea, Farmacia, Bucureşti, XLIX, (4), 62 (2001); (2003);

5. I. Gănescu, V. Aldea, A. Gănescu, I. Papa, A. Barbu, Farmacia, Bucureşti, 1,

6. I. Gănescu, A. Popescu, L. Chirigiu. I. Papa, Analele Universitătii din Bucureşti, VII, 533, (1998);

7. G. Desmuch, M. Joshi, Z. Anal. Chem., 142, 275, (1959);

8. M. Steinbach, Prelucrarea statistică în medicină şi biologie, Ed. Acad. Buc., $233(1961)$;

9. L. Batuner, M. Pozim, Metode matematice în tehnică, Ed. Tehnică Bucureşti, 186, (1956);

10. Ceauşescu D., Metode statistice expeditive în chimia analitică, Ed., Mirtan, Timişoara, pag 82, (1992). 